\title{
The common enteric bacterial pathogens and their antimicrobial susceptibility pattern among HIV-infected individuals attending the antiretroviral therapy clinic of Hawassa university hospital, southern Ethiopia
}

Ayele Kebede ${ }^{1}$, Solomon Aragie ${ }^{1}$ and Techalew Shimelis ${ }^{2^{*}}$

\begin{abstract}
Background: The frequent occurrence of bacterial gastroenteritis among HIV-infected individuals together with increased antimicrobial drug resistance pose a significant public health challenge in developing countries. This study aimed to determine the prevalence of enteric bacterial pathogens and their antimicrobial susceptibility pattern among HIV-infected patients in a tertiary hospital in southern Ethiopia.

Methods: A hospital-based cross-sectional study was conducted at Hawassa University Comprehensive Specialized Hospital from February to May, 2016. A consecutive 215 HIV-infected patients, with complaints of gastrointestinal tract disease, were enrolled. Data on socio-demography and related factors was collected using a structured questionnaire. A stool sample was collected from each study participant and cultured to isolate enteric bacterial pathogens; isolates were characterized using biochemical tests. Antimicrobial susceptibility was determined using the Kirby- Bauer disk diffusion technique.

Results: Out of 215 patients, 27(12.6\%) were culture positive for various bacterial pathogens. Campylobacter species was the most common bacterial isolate (6.04\%), followed by Salmonella species (5.1\%). The majority of isolates was sensitive to norfloxacin, nalidixic acid, gentamicin, ceftriaxone and ciprofloxacin and showed resistance to trimethoprim sulfamethoxazole (SXT) and chloramphenicol. Consumption of raw food was the only risk factor found to be significantly associated with enteric bacterial infection (crude odds ratio 3.41 95\% Cl 1.13-10.3).

Conclusions: The observed rate of enteric bacterial pathogens and their antimicrobial resistance pattern to the commonly prescribed antibiotics highlights the need to strengthen intervention efforts and promote rational use of antimicrobials. In this regard, the need to strengthen antimicrobial stewardship efforts should be emphasized to slow grown antimicrobial resistance among this population group.
\end{abstract}

Keywords: Enteric bacterial infection, HIV, Antimicrobial drug resistance, Ethiopia

\footnotetext{
*Correspondence: techalew03@yahoo.com

${ }^{2}$ Department of Medical Laboratory Science, Hawassa University, College of

Medicine and Health Sciences, P.O. Box-1560, Hawassa, Ethiopia

Full list of author information is available at the end of the article
} 


\section{Background}

Human immunodeficiency virus (HIV) associated immunosuppression increases the vulnerability of patients to various infections [1]. Enteric bacterial pathogens such as Salmonella species, Campylobacter species, Shigella species, Clostridium difficile and different strains of Escherichia coli have been identified as etiologic agents with the potential to cause severe illness in HIV-infected patients $[2,3]$. Symptoms, duration and potential for severe manifestations of enteric bacterial infections are influenced by many factors including immunity status (measured by CD4+ T cell count) and the use of highly active antiretroviral therapy (HAART) and prophylaxis. Previous research showed that patients with lower CD4+ T cell counts are more likely experience bacterial diarrhea [4]. Bacteremia due to Salmonella, Campylobacter and Shigella was also more common in those with lower CD4+ T cell counts $[5,6]$.

Gastrointestinal tract (GIT) illnesses such as diarrhea affect up to $95 \%$ of persons with AIDS, frequently causing malabsorption, significant weight loss, higher rates of extra-intestinal infections, and increased mortality in developing countries [7]. The introduction of HAART and prophylactic management of opportunistic infections has brought substantial improvements in health and life expectancy of PLHIV. Several reports from developed countries have shown the decline in diarrheal episodes (specifically bacterial diarrhea) $[4,6]$. However, these protective roles of HAART were not demonstrated in some other studies $[3,8]$.

An increasing rate of bacterial resistance to drugs commonly used to treat enteric infections further complicates the management of disease in PLWHIV. Due to the frequent exposure to antibiotic therapy and prophylaxis, HIV-infected patients might carry resistant bacterial strains [9]. In some studies, enteric bacterial pathogens with higher rate of resistance to antimicrobials were isolated from PLWHIV $[10,11]$.

In Ethiopia, information about the epidemiology of enteric bacterial pathogens in PLHIV is scant. A study that investigated HIV-infected patients in the southwest part of the country (Jimma) during the pre-HAART period showed bacterial pathogens such as Salmonella, Shigella, Campylobacter and E. coli were common [12]. In the same study, isolates were found to be less sensitive to tetracycline, chloramphenicol, gentamicin, and nalidixic acid. The present study aimed to identify bacterial pathogens and their antibiotic susceptibility pattern among HIV-infected patients attending a largest hospital in southern Ethiopia. The findings of this study will help generate evidence to inform antimicrobial stewardship efforts, and provide location -specific comparator information for similar studies undertaken in other populations.

\section{Methods}

\section{Study design and setting}

A hospital-based cross-sectional study was conducted at Hawassa University Comprehensive Specialized Hospital (HUCSH) from February to May, 2016. The hospital is situated at Hawassa, the capital city of the Southern Nation, Nationalities and Peoples' Region. The hospital is the largest in the administrative region with bed capacity of 400. The antiretroviral therapy (ART) clinic in the facility offers treatment service for new and follow-up HIV-infected clients. Clinical and immunological assessments (CD4+ $\mathrm{T}$ cell count) at enrolment and at three-monthly intervals help determine patients' eligibility for HAART. HIV-infected patients with clinical indications of GIT diseases are routinely investigated for intestinal parasites in the hospital. Stool bacterial culturing is not performed on routine basis.

\section{Population}

The study population consisted of HIV-infected patients attending the ART clinic at HUCSH during the study period and presenting with signs and symptoms of GIT disease. Patients aged $<18$ years, or who could not provide a stool sample or who had taken antimicrobial treatment (except trimethoprim-sulphamethoxazole (SXT) prophylaxis) within two weeks prior to the time of data collection were excluded.

\section{Sample size and sampling technique}

The sample size was estimated using a single proportion formula, and assuming a prevalence of enteric bacterial infection in HIV- infected patients of 16\% [12], 95\% level of confidence and 5\% margin of error. A convenient sampling technique was used to enroll study participants, in which consecutive HIV-infected patients eligible for enrollment were invited to participate.

\section{Data collection}

\section{Socio- demography and clinical data}

A structured questionnaire was used to collect sociodemographical (age, sex, residence, educational status) and other related factors (hand washing practice, habit of consuming raw food, own domestic animals, availability and usage of latrine, source and treatment of water for drinking). Patients were also asked for complaints of diarrhea (passing three or more loose or liquid stools over a 24-h period). Data on recent level of CD4+ T cell count, HAART status and prophylactic usage of SXT was obtained from patients' medical records.

\section{Laboratory testing}

Bacterial isolation and characterization A single stool sample was collected from each study participant using a sterile and disinfectant-free container. Stool samples 
were cultured on MacConkey (MAC) and Xylose Lysine Deoxychocolate (XLD) agar media after enrichment on Selenite-F Broth (Oxoid, United Kingdom). Further, blood free Campylobacter selective agar with Cefoperazone, Amphotericin B and Teicoplanin (CAT) selective supplement (Himedia, Ltd) was inoculated for isolation of Campylobacter species XLD and MAC agar plates were incubated aerobically at $37{ }^{\circ} \mathrm{C}$ for $24 \mathrm{~h}$. Agar plates for isolation of Campylobacter species were incubated under microaerophilic conditions $\left(5-10 \% \mathrm{O}_{2}\right.$ and $10 \%$ $\mathrm{CO}_{2}$ concentration) at $37^{\circ} \mathrm{C}$ for $48 \mathrm{~h}$. To create microaerophilic condition, the inoculated agar plates were kept in a gas jar containing gas generating kit (Campy $\mathrm{Gen}^{\mathrm{m}}$, Oxoid, United Kingdom). Isolates were characterized using biochemical tests. Serotyping was performed for Salmonella, Shigella and E. coli using commercial anti-sera.

Antimicrobial susceptibility test Antibiotic susceptibility testing was performed using the Kirby-Bauer disc diffusion method according to the recommendation of the Clinical and Laboratory Standards Institute (CLSI) (CLSI, 2011). In brief, 1-3 similar bacterial colonies were inoculated into a nutrient broth to prepare inoculums; broths were incubated at $37{ }^{\circ} \mathrm{C}$ for $4 \mathrm{~h}$. Turbidity of broths was standardized at $0.5 \mathrm{McF}$ arland using sterile phosphate buffered saline $(\mathrm{pH}, 7.2)$. The standardized suspension was inoculated on Mueller-Hinton agar plates. Defibrinated sheep blood (5\%) was added for susceptibility testing of Campylobacter isolates. Antibiotic discs representing commonly prescribed antimicrobials in the study area were tested; these included chloramphenicol $(30 \mu \mathrm{g})$, ciprofloxacin $(5 \mu \mathrm{g})$, trimethoprimsulfamethoxazole $(1.25 / 23.75 \mu \mathrm{g})$, erythromycin $(15 \mu \mathrm{g})$, gentamicin $(10 \mu \mathrm{g})$, nalidixic acid $(30 \mu \mathrm{g})$, norfloxacin $(30 \mu \mathrm{g})$, tetracycline $(30 \mu \mathrm{g})$, and ceftriaxone $(30 \mu \mathrm{g})$. Plates were incubated aerobically at $37^{\circ} \mathrm{C}$ for $16-18 \mathrm{~h}$; the incubation for Campylobacter species was done under microaerophilic condition for $48 \mathrm{~h}$. The diameter of inhibition zone was measured using a caliper and interpreted according to the standard (CLSI, 2011). A reference strain of $E$. coli (ATCC-25922) was tested as a control.

\section{Statistical analysis}

Data entry and analysis were performed using SPSS Version 20 software. Results were summarized using percentages and frequencies. Binary logistic regression analyses were performed and crude odds ratio with 95\% confidence interval $(\mathrm{CI})$ were calculated to measure the strength of association between the dependent and independent variables.

\section{Results}

Participants' socio-demographic and clinical profile

A total of 215 HIV-infected individuals were enrolled in this study. The participants' mean age was 30.3 years (range, 18-55 years). The most common age group represented was those aged 45 to 54 years $(34.8 \%)$. Of the study participants, $52 \%$ were females and $68.8 \%$ were residents of urban areas (Table 1). HIV infected individuals with a CD4+ T cell count $\leq 350$ cells $/ \mathrm{mm}^{3}$ accounted for $41.7 \%$. Within this group, $91.8 \%$ were taking SXT prophylaxis. The remaining individuals had either discontinued or had not started taking the prophylaxis. The majority of the respondents $(66 \%)$ received HAART with the mean duration of treatment having being 39 months (range 2-84 months). Participants who reported having diarrhea accounted for $47.4 \%$ (Table 2).

\section{Bacterial profile and distribution}

Laboratory analysis of the stool samples showed that $12.6 \%$ of the study participants had at least one enteric bacterial pathogen. The most frequent isolates were Campylobacter species (6.04\%), followed by Salmonella species (5.1\%). The rates of Shigella species and enterohaemorrhagic E. coli (EHEC) were $1.3 \%$ and $0.9 \%$, respectively. The majority of isolates (80\%) was detected among participants who reported having diarrhea at the time of data collection (Table 3).

Table 1 The occurrence and distribution of pathogenic enteric bacteria by socio-demographic characteristics in HIV- infected individuals at HUCSH, 2016

\begin{tabular}{|c|c|c|c|}
\hline Characteristics & $\begin{array}{l}\text { Number }(\%) \\
\text { tested } \\
(n=215)\end{array}$ & $\begin{array}{l}\text { Number (\%) positive } \\
\text { for enteric bacteria } \\
(n=27)\end{array}$ & $\begin{array}{l}\text { Crude odds } \\
\text { ratio }(95 \% \mathrm{Cl})\end{array}$ \\
\hline \multicolumn{4}{|l|}{ Sex } \\
\hline Male & $103(47.9)$ & $11(10.7)$ & $0.75(0.32-1.77)$ \\
\hline Female & $112(52.1)$ & $16(14.2)$ & 1 \\
\hline \multicolumn{4}{|l|}{ Age } \\
\hline $18-24$ & $25(11.6)$ & $4(16.0)$ & 1 \\
\hline $25-34$ & $50(23.3)$ & $4(8.0)$ & $0.50(0.11-2.17)$ \\
\hline $35-44$ & $58(27.0)$ & $10(17.2)$ & $1.08(0.31-3.76)$ \\
\hline $45-54$ & $70(32.6)$ & $8(11.4)$ & $0.71(0.20-2.58)$ \\
\hline$\geq 55$ & $9(4.2)$ & $1(11.1)$ & $0.07(0.01-0.65)$ \\
\hline \multicolumn{4}{|l|}{ Residence } \\
\hline Urban & $148(68.8)$ & $17(11.4)$ & 1 \\
\hline Rural & $67(31.2)$ & $10(15)$ & $0.69(0.28-1.66)$ \\
\hline \multicolumn{4}{|c|}{ Educational Status } \\
\hline Illiterate & $49(22.8)$ & $5(10)$ & 1 \\
\hline Primary & $108(50.2)$ & $12(11.1)$ & $0.92(0.31-2.75)$ \\
\hline $\begin{array}{l}\text { Secondary } \\
\text { and above }\end{array}$ & $57(27.0)$ & $10(17.2)$ & $1.08(0.31-3.76)$ \\
\hline
\end{tabular}


Table 2 The distribution of enteric bacterial pathogens in relation to CD4+ T cell count, diarrhea status and treatment status in HIV- infected individuals at HUCSH, 2016

\begin{tabular}{llll}
\hline Characteristics & $\begin{array}{l}\text { Number (\%) } \\
\text { tested } \\
(\mathrm{n}=215)\end{array}$ & $\begin{array}{l}\text { Number (\%) } \\
\text { positive for } \\
\text { enteric bacteria } \\
(\mathrm{n}=27)\end{array}$ & $\begin{array}{l}\text { Crude odds } \\
\text { ratio }(95 \% \mathrm{Cl})\end{array}$ \\
\hline $\begin{array}{l}\text { CD4+ T cell count } \\
\leq 350 \text { cells } / \mathrm{mm}^{3}\end{array}$ & $88(40.9)$ & $12(13.6)$ & $1.18(0.52-2.66)$ \\
$>350$ cells $/ \mathrm{mm}^{3}$ & $127(59.1)$ & $15(11.8)$ & 1 \\
$\begin{array}{l}\text { Diarrhea status } \\
\text { Diarrhea }\end{array}$ & $102(47.4)$ & $21(20.5)$ & $4.62(1.78-11.98)^{\mathrm{a}}$ \\
No-diarrhea & $113(52.6)$ & $6(5.3)$ & 1 \\
ART status & $82(38.1)$ & $11(13.4)$ & $0.99(0.44-2.22)$ \\
Not taking HAART & $18(13.5)$ & 1 \\
Taking HAART & $133(61.9)$ & $18(13.3)$ & $1.21(0.52-2.85)$ \\
SXT prophylaxis & & $9(11.3)$ & 1 \\
Not-taking & $135(62.8)$ & & \\
Taking & $80(37.2)$ & &
\end{tabular}

${ }^{a}$ statistically significant

SXT, cotrimoxazole; HAART, highly active anti-retroviral therapy; CD, cluster of differentiation; $\mathrm{Cl}$, confidence interval

As presented in Tables 1 and 2, the association between diarrhea status and rate of enteric bacterial isolate was found to be statistically significant, which participants with diarrhea had a higher proportion of enteric bacterial pathogens than participants without diarrhea (crude odds ratio (COR) 4.62; 95\% CI 1.78-11.98).

Table 3 Enteric bacterial pathogens isolated from HIV-infected individuals with or without diarrhea in HUCSH, 2016

\begin{tabular}{llll}
\hline Isolates & \multicolumn{2}{c}{ Diarrhea status } & $\begin{array}{l}\text { Total (\%) } \\
(\mathrm{n}=215)\end{array}$ \\
\cline { 2 - 3 } & $\begin{array}{l}\text { Diarrhea }(\%) \\
(n=102)\end{array}$ & $\begin{array}{l}\text { No-diarrhea }(\%) \\
(n=113)\end{array}$ & $11(5.1)$ \\
\hline Salmonella species & $7(6.9)$ & $4(3.5)$ & 3 \\
S. Typhi & 3 & 0 & 4 \\
S. Paratyphi A & 2 & 2 & 4 \\
S. Typhimurium & 2 & 2 & $3(1.4)$ \\
Shigella species & $3(2.9)$ & 0 & 2 \\
S. flexneri & 2 & 0 & 1 \\
S. dysenteriae & 1 & 0 & $2(0.9)$ \\
E. coli (only EHEC & $2(2)$ & 0 & 1 \\
Strains) & 1 & 0 & 1 \\
O26:H11 & 1 & 0 & $13(6.04)$ \\
O48:H21 & $11(10.8)$ & $2(1.8)$ & $29(13.4)$ \\
Campylobacter species & $23(22.5)$ & $6(5.3)$ & \\
Total & EHEC enterohaemorrhagic Escherichia coli & &
\end{tabular}

EHEC, enterohaemorrhagic Escherichia coli
The associated risk factors with enteric bacterial infections The majority of the study participants used protected water sources for drinking (88.2\%), owned a private latrine $(95.8 \%)$, and consuming raw food (65.6\%). The bacterial isolation rates were higher among participants, who sometimes used soap to wash hands at key hand washing times (15.4\%), consumed raw food (16.3\%), owned domestic animal at home (15.8\%), and had no private latrine $(22.2 \%)$. Only consumption of raw food was found to significantly increase the risk of having enteric bacterial infections among HIV-infected individuals (COR 3.41; 95\% CI 1.13-10.3) (Table 4).

\section{Antimicrobial susceptibility pattern}

It was observed that 8 of 13 tested Campylobacter isolates were found to be resistant to trimethoprim-sulfamethoxazol. Moreover, 8 of 11 Salmonella isolates were resistant to trimethoprim-sulfamethoxazol and chloramphenicol. The majority of isolates was sensitive to norfloxacin, nalidixic acid, gentamicin, ceftriaxone and ciprofloxacin (Table 5).

\section{Discussion}

A compromised immunity resulting from HIV infection hampers the intestinal defense against microbes. Consequently, enteric bacteria are common and more likely to

Table 4 The occurrence of enteric bacterial pathogens in relation to risk factors among HIV-infected individuals at HUCSH, 2016

\begin{tabular}{|c|c|c|c|}
\hline Characteristics & $\begin{array}{l}\text { Number }(\%) \\
\text { tested } \\
(\mathrm{n}=215)\end{array}$ & $\begin{array}{l}\text { Number }(\%) \text { positive } \\
\text { for enteric bacteria } \\
(\mathrm{n}=27)\end{array}$ & $\begin{array}{l}\text { Crude odds } \\
\text { ratio }(95 \% \mathrm{Cl})\end{array}$ \\
\hline \multicolumn{4}{|c|}{ Hand washing practice } \\
\hline Always & $98(45.6)$ & $9(9.2)$ & 1 \\
\hline Sometimes & $117(54.4)$ & $18(15.4)$ & $1.87(0.76-4.59)$ \\
\hline \multicolumn{4}{|c|}{ Consume raw food } \\
\hline Yes & $141(65.6)$ & $23(16.3)$ & $3.41(1.13-10.3)^{\mathrm{a}}$ \\
\hline No & $74(34.4)$ & $4(5.4)$ & 1 \\
\hline \multicolumn{4}{|c|}{ Domestic animal at home } \\
\hline Yes & $114(53.0)$ & $18(15.8)$ & $1.92(0.82-4.4)$ \\
\hline No & $101(47.0)$ & $9(8.9)$ & 1 \\
\hline \multicolumn{4}{|c|}{ Source of water for drinking } \\
\hline Protected & $191(88.8)$ & $22(11.5)$ & 1 \\
\hline Un-Protected & $24(11.2)$ & $5(20.8)$ & $2.02(0.69-5.96)$ \\
\hline \multicolumn{4}{|c|}{ Use of treated drinking water } \\
\hline Yes & $92(42.8)$ & $9(9.8)$ & 1 \\
\hline No & $123(57.2)$ & $18(14.6)$ & $1.77(0.76-4.13)$ \\
\hline \multicolumn{4}{|c|}{ Availability of private latrine } \\
\hline Yes & $206(95.8)$ & $25(12.1)$ & 1 \\
\hline No & $9(4.2)$ & $2(22.2)$ & $2.07(0.41-10.52)$ \\
\hline
\end{tabular}

${ }^{a}$ statistically significant 
Table 5 Antimicrobial resistance pattern of enteric bacterial isolates $(n=29)$ detected in stool samples of HIV-infected individuals in HUCSH, 2016

\begin{tabular}{lllll}
\hline Antibiotics & Campylobacter spp. $(n=13)$ & Salmonella spp. $(n=11)$ & Shigella spp. $(n=3)$ & E. coli $(E H E C)(n=2)$ \\
\hline Nalidixic acid & 1 & 1 & 0 & 1 \\
Gentamicin & 0 & 1 & 1 & 0 \\
Ceftriaxone & 0 & 1 & 0 & 3 \\
Tetracycline & 3 & 7 & 0 & 1 \\
Norfloxacin & 0 & 0 & 0 & 1 \\
Ciprofloxacin & 1 & 1 & 2 & 2 \\
Trimethoprim Sulfamethoxazol & 8 & 8 & 3 & 1 \\
Chloramphenicol & 7 & 8 & 2 & 1 \\
Erythromycin & 3 & 6 & & 1 \\
\hline
\end{tabular}

cause diarrhea and other invasive conditions in HIVinfected patients than healthy individuals [13]. The rate of enteric bacterial isolates in the present study was shown to be $12.6 \%$. A similar rate (16\%) was reported in a previous study in southwest Ethiopia (Jimma) [12], and other settings outside Africa, including Cambodia (12.5\%) [14] and Peru (14.5\%) [2]. Rates reported in Uganda (19.2\%) [15] and India (29\%) [16] were higher than our findings. The rate of bacterial isolation among patients with diarrhea (22.5\%) in the current study was comparable to findings in Peru (22\%) [2], Thailand (17.4\%) [17], and Uganda (21\%) [15] but lower than rates reported from India (44\%) [16] and South Africa (43.3\%) [18]. The observed differences in rates of bacterial isolation could be attributed to differences in risk factors in various populations. The number of patients with diarrhea included in different studies could also affect the rate of enteric bacterial isolates as it was shown in the present study that majority of the pathogens (80\%) were isolated from those patients who reported having diarrhea.

The predominance of Campylobacter species in the present study was similarly reported in South Africa [18] and England [3] although this bacterium was not isolated in other studies that employed similar laboratory technique $[14,16]$. The rates of Campylobacter species in Uganda (3.5\%) [15], in Peru (1.7\%) [2], and in Brazil (1\%) [19] were shown to be lower than our observation. The rate of Salmonella infection (5.1\%) in the present study was higher than a finding in Peru (1\%) [2], but lower than a result from Uganda (8.1\%) [15]. The rate of Shigella species $(1.3 \%)$ was also comparable with findings in India (1\%) [16] and Cambodia (1.3\%) [14], but lower than a result in Uganda (9.5\%) [15]. The predominance of $S$. flexineri was consistent with results in Thailand and USA [4, 17]. Similar to the studies reported elsewhere $[17,20]$, only EHEC strains (O26:H11 and O48:H21) was identified in the present study even if reports $[19,21]$ on other strains of $E$. coli were also documented.
The occurrence of enteric bacterial infection in HIVinfected individuals is thought to be the net effect of socio-demographic as well as clinical status of the infected patients. Factors like hand washing practice, contact with pet animals, consumption of raw food and others have been indicated as potential factors for acquiring enteric bacterial infection [22]. In the current study, only a habit of consuming raw food was found to increase the odds of having enteric bacterial pathogens.

It was previously reported that a higher rate $(80 \%)$ of enteric bacterial isolates among patients with $\mathrm{CD} 4+\mathrm{T}$ cell count $<200$ cells $/ \mathrm{mm}^{3}$ [4]. In contrast, the current study showed no significant difference in the rate of bacterial isolates among patients with $\mathrm{CD} 4+\mathrm{T}$ cell count above and below 350 cells $/ \mathrm{mm}^{3}$. Similar finding was reported in a study from England where $65.6 \%$ of the isolates were detected among patients with $\mathrm{CD} 4+\mathrm{T}$ cell count $>350$ cells $/ \mathrm{mm}^{3}[3]$.

The role of HAART in protecting against enteric infection through inhibition of viral replication and restoring immunity has been well documented [23]. However, the absence of association between the rate of isolation and HAART status in this study may be due to the frequent exposure of people living in poor hygienic condition to enteric bacterial infection that possibly diminishes the protective role of HAART in the present study participants. The limited effect of HAART in restoring GIT immunity was also reported [24].

Globally, increased bacterial resistance to antimicrobial agents is raising a significant concern for public health. The study showed that most bacterial isolates were resistant to tetracycline, SXT and chloramphenicol. Resistance is likely to have developed due to the unrestricted, frequent and inappropriate usage of antimicrobials in the study area. These drugs are commonly used for empirical treatment (SXT and chloramphenicol), as prophylactic before and after surgery (chloramphenicol together with other agents), and patients' own self-medication (SXT and tetracycline) [25]. The present study showed 
that most of the isolates were sensitive to nalidixic acid, gentamicin, norfloxacin, ceftriaxone and ciprofloxacin.

Our study faces several limitations. First, as for any hospital-based study, our sample may have lacked representativeness and results may not be generalizable to all HIV-infected population in the study area. Second, the small sample size of the study likely limits its power.

\section{Conclusion}

This study showed that enteric bacterial pathogens were common among HIV-infected individuals, particularly in those who experienced diarrhea. Campylobacter and Salmonella species were the predominant isolates. The observed significant association between consumption of raw food and enteric bacteria pathogens may hint at the importance of ingesting adequately cooked food to prevent infection. Most isolates were sensitive to nalidixic acid, gentamicin, norfloxacin, ceftriaxone and ciprofloxacin and a high proportion were resistant to SXT and chloramphenicol. The need to strengthen antimicrobial stewardship efforts should be emphasized to slow grown antimicrobial resistance among this population group.

\section{Abbreviations \\ AIDS: Acquired immunodeficiency syndrome; ART: Antiretroviral therapy; CLSI: Clinical and Laboratory Standards Institutes; EHEC: Enterohaemorrhagic Escherichia coli; GIT: Gastrointestinal tract; HAART: Highly active antiretroviral therapy; HIV: Human immunodeficiency virus; HUCSH: Hawassa University Comprehensive Specialized Hospital; MAC: MacConkey; MDR: Multidrug resistance; NTS: Non- typhoidal Salmonella; PLWHIV: People living with HIV; SXT: Trimethoprim-sulfamethoxazole; XLD: Xylose Lysine Deoxychocolate}

\section{Acknowledgments \\ We express our deepest gratitude to the staff of Microbiology Laboratory and ART Clinic of HUCSH who supported us with data collection. We particularly thank Mr. Tsegayea Alemayehu, Mr. Enqusilasea Mitiku, Mr. Eshetu Nigusse, Ms. Addis Gebremariam, Mr. Sahelea Demissie and Ms. Zeineba Temam for their unreserved support with the laboratory activities. We thank the study participants who volunteered to take part in this study. Our acknowledgment also goes to the HUCSH for allowing us to access the laboratory facilities and all available resources needed for this research work. We gratefully acknowledge the Hawassa University, Department of Biology for small financial support. Finally, the authors are most grateful to Mr. Adam Craig, who kindly read and edited this manuscript.}

\section{Funding}

No funding was obtained. But, Hawassa University provided minimal finance to support its postgraduate students.

\section{Availability of data and materials}

The raw data is available in SPSS file with the principal investigator.

\section{Authors' contributions}

AK, SA and TS designed the study; AK contributed to the laboratory work; AK, SA and TS performed the statistical analyses, interpretation and contributed to the write-up. All authors read and approved the final version of the manuscript.

\section{Ethics approval and consent to participate}

The study was approved by the Institutional Review Board of College of Medicine and Health Sciences of Hawassa University. Permission was also obtained from the management of the hospital. All study participants gave informed written consent, and any information obtained during the study is kept confidential. Physicians managed individuals found to be infected with pathogenic bacteria.
Consent for publication

Not applicable

\section{Competing interests}

The authors declare that they have no competing interests.

\section{Publisher's Note}

Springer Nature remains neutral with regard to jurisdictional claims in published maps and institutional affiliations.

\section{Author details}

${ }^{1}$ Department of Biology, Hawassa University, College of Natural and Computational Sciences, P.O. Box - 1560, Hawassa, Ethiopia. ${ }^{2}$ Department of Medical Laboratory Science, Hawassa University, College of Medicine and Health Sciences, P.O. Box- 1560, Hawassa, Ethiopia.

Received: 17 July 2017 Accepted: 18 December 2017

Published online: 22 December 2017

\section{References}

1. Kallings LO. The first postmodern pandemic: 25 years of HIV/ AIDS. J Intern Med. 2008;263:18-43.

2. Cárcamo C, Hooton T, Wener MH, Weiss NS, Gilman R, Arevalo J. Etiologies and manifestations of persistent diarrhea in adults with HIV-1 infection: a case-control study in lima, Peru. JID. 2005;191:11-9.

3. Datta D, Gazzard B, Stebbing J. The diagnostic yield of stool analysis in 525 HIV-1-infected individuals. AIDS. 2003;17:1711-3.

4. Sanchez TH, Brooks JT, Sullivan PS, Juhasz M, Mintz E, Dworkin MS. Bacterial diarrhea in persons with HIV infection, United States. Clin Infect Dis. 2005;41:1621-2.

5. Davies NECG, Karstaedt AS. Shigella bacteremia over a decade in Soweto, South Africa. Trans R Soc Trop Med Hyg. 2008;102:1269-73.

6. Fernández-Cruz A, Muñoz P, Mohedano R, Valerio M, Marin M, Alcala L. Campylobacter bacteremia clinical characteristics, incidence, and outcome over 23 years. Medicine. 2010;89:319-30.

7. Carcamo C, Hooton T, Wener MH, Weiss NS, Gilman R, Arevalo J, Carrasco J, Seas C, Caballero M, Holmes KK. Etiologies and manifestations of persistent diarrhea in adults with HIV-1 infection: a case-control study in lima, Peru. J Infect Dis. 2005;191(1):11-9.

8. Call SA, Heudebert G, Saag M, Wilcox C. The changing etiology of chronic diarrhea inHIV-infected patients with CD4 cell counts less than 200 cells/ mm3. AJG. 2000;95:3142-6.

9. Rossit ARB, Gonçalves ACM, Franco C, RLD M. Etiological agents of diarrhea in patients infected by the HIV-1. a review. Rev Inst Med trop S Paulo. 2009;5:59-65.

10. Kownhar H, Shankar EM, Rajan R, Vengatesan A, Rao UA. Prevalence of campylobacter jejuniand enteric bacterial pathogens among hospitalized HIV- infected versus non-HIVinfected patients with diarrhoea in southern India. Scand J Infect Dis. 2007;39:862-6.

11. Mwansa J, Mutela K, Zulu I, Amadi B, Kelly P. Antimicrobial sensitivity in Enterobacteria from AIDS patients, Zambia. Emerg Infect Dis. 2002;8:92-3.

12. Awole M, Gebre-Selassie S, Kassa T, Kibru G. Isolation of potential bacterial pathogens from the stool of HIV-infected and HIV-non-infected patients and their antimicrobial susceptibility patterns in Jimma hospital, south west Ethiopia. Ethiop Med J. 2002:40:353-64.

13. Downs JH. The gastrointestinal tract and HIV pathogenesis. SAfr J Clin Nutr. 2010;23:565-8.

14. Chhin S, Harwell Jl, Bell JD, Rozycki G, Ellman T, Barnett JM, Ward H. Etiology of chronic diarrhea in antiretroviral-naïve patients with HIV infection admitted to Norodom Sihanouk hospital, Phnom Penh, Cambodia. Clin Infect Dis. 2006:43:925-32.

15. Brink AK, Mahe C, Watera C, Lugada E, Gilks C, Whitworth J. Diarrhea, CD4 counts and enteric infections in a community-based cohort of HIV-infected adults in Uganda. J Inf Secur. 2002;45:99-106.

16. Uppal B, Kashyap B, Bhalla P. Enteric pathogens in HIV/AIDS from a tertiary care hospital. Indian J Community Med. 2009;34:237-42.

17. Suthienkul O, Aiumlaor P, Siripanichgon K, Eampokalap B, Likhanonsakul S, Utrarachkij F. Bacterial causes of AIDS-associated diarrhea in Thailand. South East Asian J Trop Med Public Health. 2001;32:150-70. 
18. Obi CL, Bessong PO. Diarrhoeagenic bacterial pathogens in HIV-positive patient with diarrhea in rural communities of Limpopo Province, South Africa. JHPN. 2002;20:230-4.

19. Rossit ARB, Gottardo de Almeida MT, Nogueira CAM, Oliveira JGC, Barbosa DMU, Moscardini AC. Bacterial, yeast, parasitic, and viral enteropathogens in HIV-infected children from Saõ Paulo state, southeastern Brazil. Diagn Microbiol Infect Dis. 2007;57:59-66.

20. Kaur P, Chakraborti A, Asea A. EnteroaggregativeEscherichia coli: an emerging entericfood borne pathogen. Interdiscip Perspect Infect Dis. 2010:1-10.

21. Gassama- Sow A, Sow PS, Fall F, Camara P, Philippe H, Gukye-N'Diaye a. ordinary and opportunistic enteropathogens associated with diarrhea in Senegalese adults in relation to human immunodeficiency virus serostatus. Int J Infect Dis. 2001;5:192-8.

22. Huang DB, Zhou J. Effect of intensive hand washing in the prevention of diarrheal illness among patients with AIDS: a randomized controlled study. J Med Microbiol. 2007;56:659-63.

23. Brenchley JM, Douek DC. HIV infection and the gastrointestinal immune system. Mucosal Immunol. 2008;1(1):23-30.

24. Guadalupe M, Sankaran S, George MD, Reay E, Verhoeven D, Shacklett BL. Viral suppression and immune restoration in the gastrointestinal mucosa of human immunodeficiency virus type 1-infected patients initiating therapy during primary or chronic infection. J Virol. 2006;80:8236-47.

25. DACA: Antimicrobials use, resistance and containment baseline survey syntheses of findings 2013.

\section{Submit your next manuscript to BioMed Central} and we will help you at every step:

- We accept pre-submission inquiries

- Our selector tool helps you to find the most relevant journal

- We provide round the clock customer support

- Convenient online submission

- Thorough peer review

- Inclusion in PubMed and all major indexing services

- Maximum visibility for your research

Submit your manuscript at www.biomedcentral.com/submit 